\title{
The Information Society
}

Professor Hiranya K. Nath ${ }^{+\check{~}}$

\section{Abstract}

This article briefly discusses various definitions and concepts of the so-called information society. The term information society has been proposed to refer to the post-industrial society in which information plays a pivotal role. The definitions that have been proposed over the years highlight five underlying characterisations of an information society: technological, economic, sociological, spatial, and cultural. This article discusses those characteristics. While the emergence of an information society may be just a figment of one's imagination, the concept could be a good organising principle to describe and analyse the changes of the past 50 years and of the future in the 21st century.

Key words: Information economy, information society, post-industrial society

\footnotetext{
${ }^{+}$Department of Economics and International Business, Sam Houston State University, Huntsville, Texas 77341-2118, USA, Email: eco_hkn@shsu.edu

IV Visiting Professor, Department of Humanities and Social Sciences, Indian Institute of Technology Guwahati, Assam 781039, India

(C) Nath 2017. This is an Open Access article distributed under the terms of the Creative Commons Attribution License (http://creativecommons.org/licenses/by/2.0), which permits unrestricted use, distribution, and reproduction in any medium, provided the original work is properly cited.
} 


\section{Introduction}

We now use more information in our day-today life than before. The volume of information available through radio, television, internet, books, newspapers, and magazines has enlarged manifold, both in developed and developing countries. Increased flows of information between parties, individuals as well as organisations, have made interactions information-intensive. As more and more people are employed in service sector jobs, even in developing countries, there is a higher intensity of information in economic activities. These developments are partly due to the structural changes that have been taking place in the economy and the society, and partly due to technological progress. Although these factors are hard to disentangle from each other, it is not very difficult to see that technology has played a very important role. The unprecedented advances in information and communication technologies (ICT) have transformed societies in both developed and developing countries in ways that were unimaginable not so long ago. The way we conduct our personal lives, the way we build and maintain interpersonal relationships, and the way we engage in production and distribution activities have undergone changes that have long-run implications for the society in general and for the economy in particular. That we can connect to each other almost anywhere in the world instantaneously, can do shopping, banking, our jobs from the comforts of the four walls of our homes, and can have access to the best of entertainment, education, medical care has definitely enhanced the quality of life.

From an economic perspective, these technological advances have affected our lives in two fundamental ways. First, by giving access to enormous amounts of information, they arguably help the economic agents make better decisions. As consumers, we now can access more information than before while making decisions about what and how much to purchase; as workers, we can access more information about available jobs and working conditions; as producers, we have more information about the supply of inputs and the demand for output. Second, by lowering transaction costs, these technologies have promoted economic efficiency. For example, in many countries (including India) the customer can pay her utility (gas, water, electricity) bills or credit card bills online. Thus, that a trip to the payment location is not required and it is not necessary to mail the check saves time. Also, the flexibility of making the payments at any time of the day adds to the efficiency and well-being of the customer. These changes have far-reaching implications beyond our economic lives. As we have been undergoing these transformations in our lifestyles and organisations of economic and social institutions, scientists and thinkers are grappling with concepts, terms, and definitions to discuss, analyse, anticipate, and hopefully to navigate the course of these transformations. While some of them have already announced the arrival of the information society, others are sceptical about a formal christening.

In this article, I will introduce and discuss various concepts related to an information society that have emerged over the years. In this discussion, the reference to the information society should be interpreted as an organising principle for analysing the changes that have taken place. Further, relatively more space will be devoted to a discussion on the information economy as economic changes have been highlighted in all different strands of thinking on the information society.

\section{What is information?}

What exactly is information? A semantic definition of information highlights three aspects of information: first, information is meaningful data (about something or someone) that may result from a systematic investigation; second, communication and reception are integral parts of information; and third, information has effects. ${ }^{1}$ However, the

1 The dictionary meanings of the word 'information' include: the communication or reception of knowledge or intelligence; the knowledge obtained from investigation, study, or instruction; the attribute inherent 
definition of information depends on which characterisation of an information society, discussed below, is used. In the information society where technology is the defining characteristic, information is defined in terms of the probabilities of occurrence of symbols and its quantity is measured in bits. In the economic exposition of the information society, information is defined as the "data that have been organized and communicated" (Porat and Rubin, 1977, Vol. 1, p. 2). Some economists, most notably Machlup (1962), treat information to be synonymous with knowledge. By assigning monetary value to various economic activities, economists also try to obtain a quantitative measure of information. But as Machlup (1980: p. 23) puts it, the "endeavor to put dollar tags on such things as education, research, and art" unavoidably abandons the semantic qualities of information. In the cultural definition of the information society, the loss of meaning of symbols (information) due to profusion of information has been a major concern. But, as I will discuss below, this state of meaninglessness and the efforts to get around it, have created, to some extent, the cultural edifice of the new society.

\section{The Information Society}

The term information society has been proposed to refer to the post-industrial society in which information plays a pivotal role. It is a much broader concept than that of an information economy. However, there is no general agreement on one definition or on the defining characteristics. Over the last half century, there have been several efforts to conceptualise the essential characteristics of an

in and communicated by one of two or more alternative sequences or arrangements of something (as nucleotides in DNA or binary digits in a computer program) that produce specific effects; a signal or character (as in a communication system or computer) representing data; something (as a message, experimental data, or a picture) which justifies change in a construct (as a plan or theory) that represents physical or mental experience or another construct; a quantitative measure of the content of information; specifically, a numerical quantity that measures the uncertainty in the outcome of an experiment to be performed (http://www.merriamwebster.com/). information society, in which direction, according to some thinkers, the society will evolve. In various definitions that have been proposed over the years, there are five underlying characterisations of an information society: technological, economic, sociological, spatial, and cultural. I will briefly discuss each of them. ${ }^{2}$

\section{Technological}

The wide-ranging innovations in information and communications, from cable and satellite television, personal computers, to internet, since the late 1970s, have been purported to revolutionise our way of life in such a way that it will define a new social order (Evans, 1979; Martin, 1978). Toffler (1980), in fact, suggests that the advances in information and communication technologies (ICT) herald the third wave of technological innovation, the information revolution. ${ }^{3}$ These technologies, sometimes referred to as general-purpose technologies, have already had widespread impact on businesses, politics, and even personal lives, much beyond what was expected. For example, because of ICT it is now possible to design trousers or a dress in the U.S., to get it stitched in Bangladesh, to develop the marketing strategies in Britain, and to sell it in the U.S. This kind of internationally disaggregated production process has been possible even in the production of services. The result is a more efficient production that benefits both producers and consumers. In democracies, the participation of the people in debates and discussions on issues important to the society has been more direct and democratic. Distance learning facilitated by ICT has not only benefited people in developed countries but also in developing countries like India. In personal life, keeping contact with family and friends, making friends, even finding matrimonial matches have been greatly influenced by these innovations. The exchanges

\footnotetext{
2 These characterisations are based on the discussion in Webster (2002). However, Webster (2002) uses the term occupational for sociological characterisation.

3 The first two are the agricultural and industrial revolution respectively.
} 
of information in these instances through an ICT infrastructure, or a more radical idea of information super highways, largely facilitated by technology, have been the basic tenet of an information society. Drawing on Schumpeter's creative destruction of major technological innovations and Kondratieff's long waves of economic development, some researchers including Freeman (1987) argue that ICT innovations are the harbinger of a new epoch that will have longer-term economic benefits. The information age is set to mature in the 21st century (Hall and Preston, 1988)

The problem with this line of thinking is that these commentators do not provide a quantitative measure of ICT nor a threshold where a society can be described to have entered the information age. Such a measure should be central to any acceptable definition of an information society. Furthermore, this thesis of an information society accords the primary role to technology for social change. The underlying assumption appears to be that technology is self-perpetuating and society merely responds by adjusting its various aspects. But this suggestion that technology (or advances in it) is determined outside the realm of society is unrealistic. Technological advances and innovations, more often than not, are the results of conscious decisions of a society that focuses on achieving certain goals. However, the innovations often have wider implications much beyond what they were intended for. In the 1950s, computer engineering was developed as a part of the military research during the Cold War period. But since the 1970s, computer technology has received much wider applications beyond military purposes. Also, technological innovations reflect social values. For example, the design of a car intended for a family reflects the presumption of a family with two adults and two children.

\section{Economic}

The structure of the economy and its recent changes, in which information has come to play a defining role, has been described to constitute the information economy. It is hard to find a widely accepted, consensus definition of an information economy. In general, this is a term used to describe a phase of the postindustrial economy that is increasingly based on information-related activities. This term, however, involves certain degree of vagueness as information activities are difficult to define and measure. Knowledge economy, new economy, internet economy are some of the terms alternately used to refer to the same or a part of the same idea as is information economy.

The study by Porat and Rubin (1977) is perhaps the first to use the term information economy in a precise way by defining various related terms and devising a way to measure information- related activities in the U.S. However, their concept of an information economy was preceded by that of a knowledge industry. In his seminal book, Machlup (1962) emphasises two meanings of knowledge: one as what is known and the other as the state of knowing. In his exposition, he also clarifies that information is essentially knowledge and therefore, he does not use these terms as two separate concepts. Based primarily on these two meanings, he continued developing a scheme to measure the size of the industry that is broadly involved in production and distribution of knowledge. He argues, "as an economy develops and as society becomes more complex, efficient organization of production, trade, and government seems to require an increasing degree of division of labor between knowledge production and physical production." ${ }^{4}$ Machlup's conceptual framework was the foundation for the extensive statistical study on the U.S. Information Economy conducted by Porat and Rubin (1977). However, their methodology of measuring the information economy was distinctly different from Machlup's. Under their scheme, the economy is divided into two distinct but inseparable domains: one "involved in the transformation of matter and energy from one form into another" and the other "in transforming information from one pattern into another" where information is defined as the

\footnotetext{
${ }^{4}$ Machlup (1962), pp. 6
} 
"data that have been organized and communicated." (Porat and Rubin, 1977, Vol. 1, p. 2) The term material is used to refer to the first domain, and information to refer to the second domain. An operational definition of information encompasses "all workers, machinery, goods, and services that are employed in processing, manipulating, and transmitting information." (Porat and Rubin, 1977, Vol. 1, p. 2) Accordingly, an accountant, a teacher, a book, a telephone, or a computer belongs to the information domain, whereas a gardener, soap, a table, or a refrigerator belongs to the material domain.

Machlup (1962) distinguishes five sectors of the knowledge economy: education, research and development, mass media, information technologies, and information services. Under Porat's scheme, the information sector is further subdivided into the primary information sector (PRIS) which is engaged in the production of information goods and services; and the secondary information sector (SIS) which represents the part of the value created by information workers, information capital, and information activity of the proprietor in the process of production of a material good or a material service. The total value added of an industry belonging to the PRIS is counted as part of the information domain of the economy. For example, the total value added generated by the semiconductor industry (semiconductor is an information product) and the telecommunication industry (telecommunication is an information service) will be part of information economy value added. In case of an industry belonging to SIS, only a part of the value added is counted towards information economy. Thus, information value added of an SIS industry includes (1) employee compensation of information workers, (2) part of proprietors' income and corporate profits earned for performing informational tasks, and (3) capital consumption allowances on information machines. For example, for the textile industry (textile is a material product) or in the transportation industry (transportation is a material service), only the value-added contributions of the information workers (such as managers or accountants), the information capital (such as computers) employed in those industries, measured by wages and depreciation on information capital respectively plus a part of the proprietors' income and corporate profits are counted as part of the information economy. Thus, for these two industries the total value added will be decomposed into a material component and an information component.

The most formidable challenge of obtaining a comprehensive measure of the information economy is to separate information from the material component of the economy. The seminal works by Machulp (1962 and 1980) and Porat and Rubin (1977) outline schemes for measuring the information or, as Machlup calls it, the knowledge component of the total value generated in the economy. Unfortunately, there have been only a few studies that implement their schemes. Following Machlup's methodology, Huber and Rubin (1986) present measurements of knowledge industry in the U.S. for the years when the U.S. Bureau of the Census conducted economic censuses. These census years include 1963, 1967, 1972, 1977, and 1980. Contrary to expectations of high growth of the knowledge industry as documented by Machlup in his 1962 study, they find that its contribution to the U.S. GNP increased from 29 percent in 1958 to only about 34 percent in 1980. Further, as mentioned above, Organization for Economic Co-operation and Development (OECD, 1981 and 1986) uses Porat's methodology to measure the size of the information economy in the U.S. along with eight other member countries. This study shows that the share of the information economy in the U.S. GNP increased from $42.7 \%$ in 1958 to 49.2 percent in 1972 (OECD, 1981). In a recent study on the U.S. information economy, Apte and Nath (2007) further show that the share of the information economy in total GNP grew from about $46 \%$ in 1967 (as measured by Porat and Rubin, 1977) to about $56 \%$ in 1992 and to $63 \%$ in 1997. The study also indicates that during this time period, the share of service sector 
information activities in total GNP increased substantially, while the shares of non-service sectors declined correspondingly. The industries displaying the highest growth rates include business, medical, and educational services.

Among other attempts to quantify information economy, the Cisco Systems project on Internet Economy at the University of Texas - Austin (2000), and the study on total value of private enterprise documents by Michael K Bergman (2005) at BrightPlanet Corporation are noteworthy. However, both these studies lack a comprehensive analytical framework that would make their estimates comparable to the conventional macroeconomic data. Recently, the U.S. Census Bureau and the Bureau of Economic Analysis (BEA) have created a separate information sector that is defined to include selected publishing activities, telecommunications, data processing services, radio, television, motion picture, and video only, and for which they report data. But this definition of information sector or economy seems too restrictive, and does not reveal much about the importance of information in the new economy.

Furthermore, there have been attempts to define information economy by providing statistical accounts of employment patterns along information versus material (noninformation) dichotomy. Using decennial census data on employment by detailed occupations and industries between 1950 and 2000, Wolff (2006) finds that information workers increased from $37 \%$ of the workforce in 1950 to $59 \%$ in 2000 in the United States. He aggregates the occupations into four categories: (a) knowledge producers; (b) data processors; (c) service workers; and (d) goodsprocessing workers and call the workers in the first two categories the information workers. His analysis shows that the growth of information workers is not attributable to a change in tastes for information-intensive goods and services but partly to changes in production technology that make it possible to substitute goods and service workers by information workers, and partly to differential rates of productivity movements among the industries of the economy. Apte, Karmarkar, and Nath (2007) also examine employment and wages among information and non-information workers in the product and service sector. According to this study, information workers in the service sector with a share of about $41 \%$ of total employment lag behind non-information workers in the same sector with an employment share of about $45 \%$. However, the information workers account for the largest share in total wage bill with about $48 \%$. Because this analysis is based on data for 1999 only, we do not know much about the trends in employment and wages of information workers in recent years.

The major criticism against the economic definition of an information society is related to the issue of quantifying the information component of the economy. By assigning monetary values, this approach tends to undermine the qualitative heterogeneity and relative importance of various types of information. Furthermore, when information economy is defined in terms of the employment patterns of the information workers, it is hard to distinguish between information and non-information occupations because such a distinction is a matter of degree, not of kind. Thus, any attempt to dissect an occupation into information and non-information components will be ad-hoc, at best.

\section{Sociological}

Sociologists have conceptualised the information society in terms of changes in occupational structure and consider the preponderance of information work in occupations to have created a new social order. The beginning of this school of thought is often credited to Daniel Bell (1973), who, in his theoretical exposition of the post-industrial society, characterised by a shift from blue-collar manual jobs to white-collar jobs, recognises the importance and pre-eminence of information in white-collar service jobs. His idea of the information society based on the underlying 
structural change of the economy has some resonance in relatively recent writings. These writings focus on the transformative power of information. Information here is what is drawn upon and generated in occupations or embodied in people through education and experiences. Thinking smart, being inventive, and having the capacity to develop and exploit networks is the key to the new weightless economy (Coyne, 1997; Dertouzos, 1997). It is not physical effort but "ideas, knowledge, skills, talent, and creativity" that create wealth in this new economy (Leadbeater, 1999: p. 18).

Although based on underlying economic changes, and therefore, somewhat related to the economic exposition discussed above, the sociological view is concerned with the consequences of the growth of information occupations for social life. In this context, although a precise quantitative account is irrelevant, it is important to identify the sources of growth in information occupations. A simple example may help. Because of the advances in ICT, we have seen a substantial growth in software and telecommunication engineering and call centre jobs in India, which are all information occupations. Also, because of government reforms and economic liberalisation, there has been a significant growth of social workers who work for nongovernmental organisations (NGOs). These social workers are also classified as information workers. Thus, the mere statistics on information occupations will not reveal much about the impact of the growth of these different types of information workers. In hightech occupations, the workers have more flexibility in terms of the location of their work, the social environment, the travels, and interactions. On the other hand, since the call centre workers in India mainly cater to a western clientele, they work mostly at night, thus having a very different lifestyle from someone who works for the government. The social workers will have more interactions with people in the rural areas. But with access to the global world they may have a much broader view, which they may pass along to the people, they work for.
The growth of the different types of information workers has very different social outcomes. The resultant social hierarchies and interrelations are different in the above instances. Workers in high-tech occupations may create an elite professional class with little interaction with other groups in the society. Because of their specialised skills and the nature of their jobs, they tend to form an exclusive social network. Commenting on the rise of these professionals mainly in the western world, Perkin $(1989$, p. 2) suggests that these professionals rule by virtue of "human capital created by education and enhanced by ... the exclusion of the unqualified." As these professionals rise to the pre-eminence in the society, the traditional values and ideals of cooperation and solidarity, of property and the market, and of the paternal gentleman are likely to be replaced by the professional ethos of service, certification, and efficiency. These professionals are mainly the intellectuals and technical intelligentsia, also referred to as the new class by Gouldner (1978). They can contest the control of established business and party leaders. However, they are not a homogeneous group in terms of their political and social views. There are professionals who are technocratic and conformists as well as humanist intellectuals who are critical and emancipatory in orientation. Thus, the sociological definition of the information economy is about social hierarchies, power structure, and class relations that result from the growth of information occupations. However, since this view does not rely on any quantitative measure, it is less precise and therefore silent about when exactly we can say that a society has become an information society.

\section{Spatial}

This line of thinking on information society builds around the notion of space, although not completely detached from the economic and social aspects. The impact of information networks on the organisation of space and time has been the focal point of this discourse. We can think of a society in which people are 
connected through the information networks, the wired society, that operates at the local, regional, national, and global level to provide an "information ring main" (Barron and Curnow, 1979: p. 33)..$^{5}$ It has removed the constraints imposed by time and space. The physical location of an individual has diminished significance as long as he/she is connected/ subscribed to this worldwide information networks. These networks themselves are expanding their reach and capabilities (Urry, 2000) and, as a result, have diminished the constraints of time and distance. We may not have a direct experience of the realm of cyberspace but we must come close to it in our use of departmental store, banks, and most modern services that we can think of. In this network society, the process of production has been global in space and continuous in time. A corporation may run its production worldwide 24 hours a day, 7 days a week, and 52 weeks a year: when the American workers get off from work, their Japanese counterparts start working where the Americans left off.

This definition also runs into criticism because of lack of precision. First of all, it is not clear what a network is: is it two people talking over phone or a group of people chatting in a chat room over the internet or is it a computer system transferring a vast dataset over the computer network? How do we distinguish between different levels of networks? At which stage of networking does a society enter an information society? The commentators are also not very clear about whether networks should be defined in technical terms or in terms of volume and value of information transmitted through these networks. Some critics argue that there have existed information networks throughout history. For example, the postal services, through telegraph and telephone facilities, established information networks a long time ago. Modern ICT may have accelerated the pace of establishment of these networks, but that, itself, does not seem to make a case for a new era, a new social order, according to these critics.

\section{Cultural}

The cultural conception of an information society is closely related to the information environment in which we now live. This environment has been more penetrative, more intimate, and more constituent of our everyday lives. There are several dimensions to this development. First, there has been an extraordinary increase in information in social circulation due mainly to technological advances. Access to a wide range of news and analysis, entertainment, personal and community help from across the globe through various media: radio, television, internet, newspapers, and magazines, almost anywhere and anytime, has ushered the coming of a media-laden society. In this new social order, while there is the freedom of choice with regard to a particular medium, the penetration of some level of information in everyday life has been inevitable. Second, social interactions have become more complex and verbal and written communications have been inadequate to keep up with these complexities. As a result, for example, the symbolic import of dress and the body has dramatically increased. In the agrarian peasant society or even in the industrial society, clothes were just a way of satisfying one basic human need and the uniformity of clothes of the peasants or the industrial workers downplayed any other purpose. The availability of cheap and fashionable clothing and the possibilities of affording it enhanced the usefulness of clothing and make-up as important ways of signalling status, power, and affiliation. Third, the excessive penetration of information has also created problems. According to some commentators, as "there is more and more information, [there is] less and less meaning"

\footnotetext{
${ }^{5}$ Here the idea is very similar to an electric power grid that runs through a state or a country and is accessed by individual households or firms.
} 


\section{DOI: http://dx.doi.org/10.20896/saci.v4i3.248}

(Baudrillard, 1983, p. 95). Signals come from so many directions, and are so diverse, fast changing and contradictory, that their power to signify is dimmed. Therefore, there is a need for managing the information contents of the various ways that we try to convey or communicate with signs and information. The involvement of public relations experts in managing the images of politicians, movie stars and other celebrities is nothing but a fallout of such fear.

\section{Conclusion}

In this article, we briefly discuss various definitions and concepts of the so-called information society. However, many thinkers, including Webster (2002) and May (2002), raise doubts about the actual coming of an information society. While the emergence of such a society may be just a figment of one's imagination, the concept could be a good organising principle to describe and analyse the changes of the past fifty years and of the future in the twenty-first century. We have lived through changes that we could not imagine not long ago. The society- wide, far-reaching implications are yet to be known.

\section{References}

Apte, Uday M., Uday S. Karmarkar and Hiranya K. Nath (2008). , Information Services in the US Economy: Value, Jobs and Management Implications, California Management Review 50, 12-30.

Apte, Uday M., and Hiranya K Nath (2007). Size, Structure and Growth of the U.S. Information Economy. In U.M. Apte and U.S. Karmakar (eds): Managing in the Information Economy: Current Research Issues, Norwell (MA): Springer Science and Business Media, LLC, 1-28.

Barron, Iann and Ray Curnow (1979). The Future with Microelectronics: Forecasting the Effects of Information Technology. London, UK: Frances Pinter Ltd.

Baudrillard, Jean (1983). In the Shadow of the Silent Majorities, or The End of the Social and Other Essays. Translated by Paul Foss, John
Johnson and Paul Patton. New York: Semiotext(e).

Bell, Daniel (1973). The Coming of PostIndustrial Society: A Venture in Social Forecasting. Revised Edition. New York: Free Press.

Bergman, Michael K. (2005). "Untapped Assets: The \$3 trillion Value of U.S. Enterprise Documents." White Paper, lowa City, IA: Bright Planet..

Coyne, Diane (1997). The Weightless Economy. Oxford: Capstone.

Dertouzos, Michael L.(1997). What Will Be: How the World of Information Will Change Our Lives. London, UK: Piaktus..

Evans, Christopher (1979). The Mighty Micro: The Impact of the Computer Revolution. London, UK: Gollancz..

Freeman, Christopher (1987). Technology Policy and Economic Performance. London (UK) and New York (USA): Pinter Publishers.

Gouldner, Alvin W (1978). "The New Class Project," Theory and Society, 6, 153-203.

Hall, Peter and Paschal Preston (1988). The Carrier Wave: New Information Technology and the Geography of Innovation, 1846-2003. Boston, MA: Unwin Hyman.

Huber, Mary Taylor and Michael Rogers Rubin (1986). The Knowledge Industry in the United States: 1960-1980, Princeton, NJ: Princeton University Press.

Leadbeater, Charles (1999). Living on Thin Air:

The New Economy. London, UK: Viking.

Machlup, F. (1962). The Production and Distribution of Knowledge in the United States, Princeton, NJ: Princeton University Press.

Machlup, F. (1980). Knowledge: Its Creation, Distribution and Economic Significance, Volume 1: Knowledge and Knowledge Production, Princeton, NJ: Princeton University Press.

Martin, James (1978). The Wired Society. Englewood Cliffs, NJ: Prentice Hall. 
May, Christopher (2002). The Information Society: A Skeptical View. Cambridge, U.K.: Polity Press.

OECD (1981). Information Activities, Electronics and Telecommunications Technologies: Impact on Employment, Growth and Trade, volumes I and II, Paris.

OECD (1986). Trends in The Information Economy, Paris.

Perkin, Harold (1989). The Rise of Professional Society: Britain since 1880. London (UK) and New York (USA): Routledge.

Porat, Marc U and Michael R. Rubin (1977). The Information Economy (9 volumes), Office of Telecommunications Special Publication 77-12. Washington D.C.: US Department of Commerce.

Toffler, Alvin (1980). The Third Wave. New York, USA: Bantam Books.
University of Texas, Austin and Cisco Systems (2000). Measuring the Internet Economy. (Retrieved on April 1, 2006 from http://www.internetindicators.com).

Urry, John (2000). Sociology beyond Societies: Mobilities for the Twenty-first Century. London, UK: Routledge.

Webster, Frank (2002). Theories of the Information Society. Second Edition. London and New York: Routledge.

Wolff, E. N. (2006), "The Growth of Information Workers in the US Economy, 1950-2000: the Role of Technological Change, Computerization, and Structural Change," Economic Systems Research 18, 221-255.

\section{Acknowledgement}

This article was previously published in SIBCOLTEJO - A Journal of the SCTU, Vol. 4, pp. 19-29 (2009). It has been republished with the author's permission. 